\title{
Enhancement of Fecal Sludge Conversion Into Biogas Using Iron Powder During Anaerobic Digestion Process
}

\author{
Ignace Chabi Agani ${ }^{1}$, Fidèle Suanon ${ }^{1,2, ~ *, ~ B i a o u ~ D i m o n ~}{ }^{1}$, Edouard Binessi Ifon ${ }^{1}$, Frank Yovo ${ }^{1}$, \\ Valentin Dieudonné Wotto ${ }^{1}$, Olusegun Kazeem Abass' ${ }^{2}$, Mathieu Nsenga Kumwimba ${ }^{3}$ \\ ${ }^{1}$ Laboratory of Physical Chemistry, University of Abomey-Calavi, Republic of Benin, Cotonou, Benin \\ ${ }^{2}$ Key Laboratory of Urban Pollutant Conversion, Institute of Urban Environment, Chinese Academy of Sciences, Xiamen, China \\ ${ }^{3}$ Key Laboratory of Mountain Surface Processes and Ecological Regulation Chinese Academy of Sciences, Chengdu, China
}

\section{Email address:}

ignace.agani@gmail.com (I. C. Agani),officielsuanon@yahoo.com (F. Suanon), fideldimon@yahoo.fr (B. Dimon), binessiedouardifon@gmail.com (E. B. Ifon),yovofranck62@gmail.com (F. Yovo),bommow@yahoo.fr (V. D. Wotto), segunabass@iue.ac.cn (O. K. Abass), mathieunsenga@imde.ac.cn (M. N. Kumwimba)

${ }^{*}$ Corresponding author

\section{To cite this article:}

Ignace Chabi Agani, Fidèle Suanon, Biaou Dimon, Edouard Binessi Ifon, Frank Yovo, Valentin Dieudonné Wotto, Olusegun Kazeem Abass, Mathieu Nsenga Kumwimba. Enhancement of Fecal Sludge Conversion Into Biogas Using Iron Powder During Anaerobic Digestion Process. American Journal of Environmental Protection. Vol. 5, No. 6, 2016, pp. 179-186. doi: 10.11648/j.ajep.20160506.15

Received: December 3, 2016; Accepted: December 12, 2016; Published: January 9, 2017

\begin{abstract}
Anaerobic digestion is often used to stabilized and convert organic wastes into methane and biological fertilizer. However, when applied to fecal sludge, it doesn't yield good methane due to its high content of nitrogen. Here we have conducted anaerobic digestion of fecal sludge in the presence of iron powder (Fe) as electron donor. Results showed that $4822.7 \mathrm{~mL} \mathrm{CH}_{4} \mathrm{~kg}^{-1}$ was successfully recovered from fecal sludge in the control. The use of $\mathrm{Fe}$ in the anaerobic bio-digester remarkably improved methane yield. Indeed, up to $9933.3 \mathrm{~mL} \mathrm{CH}_{4} \mathrm{~kg}^{-1}$ wet sludge was recovered when Fe is properly used (1 $\mathrm{g}$ Fe for $400 \mathrm{~g}$ wet weight), compared to $4822.7 \mathrm{~mL} \mathrm{~kg}^{-1}$ in the control. The concentration of methane in the produced biogas increased from $58.0 \%$ in the control to $72.5 \%$ and $77.6 \%$ in the presence of iron powder, respectively at the dose rate of $0.5 \mathrm{~g}$ Fe and $1 \mathrm{~g}$ Fe per $400 \mathrm{~g}$ wet sludge. COD removal efficiency was also greatly improved. $65.5 \%$ of COD was removed when excreta was properly spiked with $\mathrm{Fe}(1 \mathrm{~g} \mathrm{Fe}$ ) against $42.2 \%$ in the control. This corresponds to an increasing rate of $23 \%$. Furthermore, the presence of $\mathrm{Fe}$ in the digesters considerably reduced the odor by trapping produced sulphur ion and prevent the formation of $\mathrm{H}_{2} \mathrm{~S}$ responsible for the sickening odor.
\end{abstract}

Keywords: Fecal Sludge, Anaerobic Digestion, Valorization, Iron Powder, Methane

\section{Introduction}

Fecal sludge known as excreta is the rejected waste by human. It constitutes one of the greatest and dangerous wastes, which management still remains a great challenge worldwide. Tons of it are generated each day and its management varies from one region to another across the world. In advanced countries, fecal sludge is being valorized not only as biogas source but also as soil amendment after being stabilized via anaerobic digestion or co-composting with others organic materials [1-2]. As a consequence, the basic sanitation coverage rate is nearly $95 \%$ while many countries in developing world found difficulty to achieve $75 \%$ coverage; which is Millennium Development Goals for sanitation [3]. In 2014, it was reported that nearly 2.5 billion people were without enhanced sanitation, of which about 1 billion people practiced open defecation [3]. Further investigation by the same institution revealed that Sub-Saharan Africa, Oceania and Southern Asia, were the most vulnerable regions characterized by the lowest sanitation coverages (30\%, 35\% and $42 \%$, respectively). Mostly in Africa, waste management represents a great challenge; the technology to encounter the challenges are often not 
available at local level. Such situation lead to a chronic fecal-oral contamination, pathogen dissemination and water contamination; which represent one of the main factors responsible of the death of over $50 \%$ of child in the developing countries [3-5]. According to Bill and Melinda Gates Foundation [6], food and water contamination with fecal natter are the cause of diarrhea of over 2.5 billion children and the death of 600,000 children. The treatment and management of liquid and solid wastes has become one of the center of interest in scientific research. Otherwise, the search of the development of alternative renewable energy sources and to upgrade the conversion of organic materials into biogas keep growing [7].

Anaerobic digestion (AD) is a well-established process in which bacteria convert organic wastes to a methane and $\mathrm{CO}_{2}$ gas mixture (generally about $60 \%$ methane and $40 \%$ $\mathrm{CO}_{2}$ ) called biogas and into a value added by-product know as biological fertilizer rich in nitrogen and phosphorous for the benefit of crops [8-9]. However, if many organic wastes can easily be converted to produce biogas and stabilized fertilizer, it is not the case with fecal sludge. Indeed, little is known about fecal sludge anaerobic digestion. This could be justified by the repulsive nature of this waste and the connotation or the view human has regarding fecal sludge. Snell [10] was the first to investigate on this issue, he reported a production of $0.5 \mathrm{~m}^{3}$ $\mathrm{kg}^{-1}$ VS during anaerobic digestion. The same author reported the inhibition of anaerobic digestion when mixing feces and urine as result of high concentration of nitrogen in the latter. Colón et al. [11-12] performed undiluted simulant human excreta in mesophilic condition; and reported that biogas yield ranged 0.24 to 0.44 NL biogas $\mathrm{g}^{-}$ ${ }^{1}$ COD and COD removal efficiency was about $80 \%$. Others studies [13-14] just focus on treating and removing COD from fecal sludge.

$\mathrm{C}$ : $\mathrm{N}$ ratio of fecal sludge is generally low due to the high concentration of nitrogen in this matter. This factor often limits anaerobic digestion process of the matter and leads to low biogas production. In addition, it has been reported that during anaerobic digestion of human excreta, there is high production of sulfuric acid $\left(\mathrm{H}_{2} \mathrm{~S}\right)$ which is harmful to bacteria growth, limit biogas production and it is finally responsible of undesirable sickening odor [15]. Otherwise, it is known that that providing of electron donor in anaerobic reactor can improve the digestion process and biogas yield. To this end, iron zero valent (nZVI), micro iron pounder (IP), and iron scrap have been successfully used to enhance methane yield during various organic wastes [16-20], elimination of odors (such as $\mathrm{H}_{2} \mathrm{~S}$ ), and better sludge stabilization $[15 ; 21]$ during anaerobic digestion process. However, despite the wide application of electron donors during anaerobic digestion, it application in fecal sludge digestion has not yet been documented.

Therefore the objective of this study is investigate the effect of micro iron powder during anaerobic digestion of fecal sludge. The effect of iron powder on methane gas production, COD removal and sludge stabilization for reuse as organic fertilizer in agriculture will be examined. To the best of our knowledge, this is the first report on the application of electron donor during fecal sludge anaerobic digestion.

\section{Materials and Methods}

\subsection{Fecal Sludge and Micro Iron Powder}

Fecal sludge used as a substrate in this study was a freshly deposited feces collected from a household. Feces was collected in a $500 \mathrm{~mL}$ glass bottles and brought to the laboratory. The sludge underwent pretreatment which consisted into the determination of physicochemical parameters such as $\mathrm{pH}$, water content $(\mathrm{W})$, dry matter (DM), organic matter (OM), total organic carbon (TOC), volatile matter (VM), chemical oxygen demand (COD) and the total Kjeldahl nitrogen (TKN) determination. Iron powder (purity $>98 \%$ and diameter $0.2 \mathrm{~mm}$ ) was purchased from Sinopharm Chemical Reagent Co. Ltd.

\subsection{Analytical Methods}

The $\mathrm{pH}$ was measured in the fresh sample after being diluted to $15 \%$ total solids. A multi parameters HANNA COMBO was used. Water content, alkalinity, COD and OM were determined according to the American standard for the examination of water and waste water [22]. The total organic carbon (TOC) was determined from OM following the equation (1) [23]. TKN was determined according to French norm AFNOR NFT90-110.

$$
\mathrm{TOC}=\frac{\mathrm{OM}}{1.8}
$$

\subsection{Experimental Setup for Biogas and Methane Measuring}

The experimental setups was at first set to monitor the production of raw biogas and secondly to directly measure the volume of methane. The bioreactor design was inspired from study carried out by [24]. Briefly, the digester was consisted of a $1000 \mathrm{~mL}$ glass bottle. A hole was perforated on the cover of the bottle and through this orifice, the digester was connected via a PVC pipe to a calibrate glass cylinder containing tap water. The biogas produced in the digester passes through the connection pipe to reach the calibrated cylinder; under which it generate bubbles to ascend to the bottom and generate a pressure which displace the tape water. The displacement of water is equal the volume of biogas produced. The entire dispositive is shown schematically in Figure 1. The use of $\mathrm{NaOH}$ afterward permitted to absorb unwanted gases and trace gas such as carbon dioxide $\left(\mathrm{CO}_{2}\right)$ and hydrogen sulfide $\left(\mathrm{H}_{2} \mathrm{~S}\right)$ in order to directly determine the volume of methane generated. 




Figure 1. Setup for produced biogas measurement.

Description: (1) Anaerobic Digester (2) bottle containing the $\mathrm{NaOH}$ solution, (3) support, (4) calibrate glass cylinder containing tap water, container (5), (6) connection pipe, (7) gas purification system

\subsection{Experimental Design}

Four (4) batches experiments were set up. In these series of experiments, fecal sludge was enriched with iron powder at different concentrations: A ( $400 \mathrm{~g}$ sludge $+0 \mathrm{~g} \mathrm{Fe}), \mathrm{B}(400$ g sludge $+0.5 \mathrm{~g} \mathrm{Fe}) \mathrm{C}(400 \mathrm{~g}$ sludge $+1 \mathrm{~g} \mathrm{Fe})$, and D (400 g sludge $+3 \mathrm{~g} \mathrm{Fe}$ ). The samples were well mixed and diluted with distilled water to $15 \%$ dry matter (DM) and homogenized by mechanical agitation [24-25]. No pH adjustment was proceeded as the later was in the range of neutrality, favorable condition for bacterial activity [26-27]. Digesters were loaded and kept in a water bath at $45^{\circ} \mathrm{C}$ (thermophile condition) for 17 days (Figure 2).

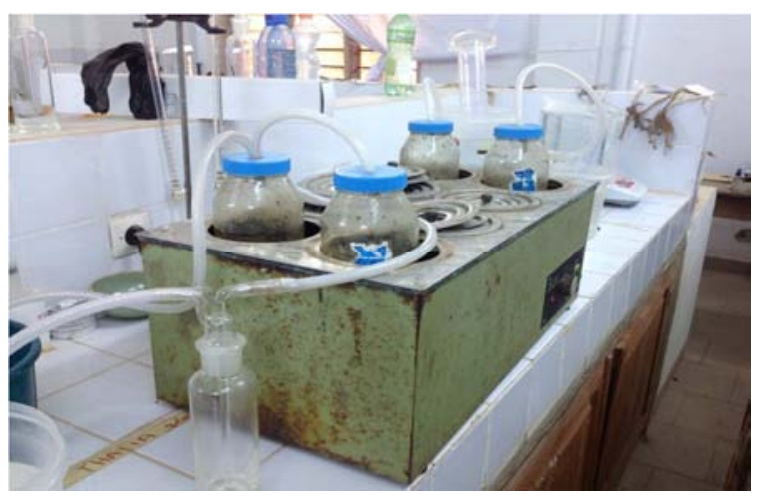

Figure 2. Image showing anaerobic digestion in progress.

\section{Results and Discussion}

\subsection{Physicochemical Parameters of the Raw Excreta}

The main physicochemical parameters determined are shown in Table 1. Data showed that fecal sludge has a near neutral ( $\mathrm{pH}$ 7.6) favorable for a good anaerobic digestion. Excreta have a high organic matter content $(94.7 \%$ dry matter) highlighting the probable presence of high proportion of biodegradable matters. Fecal sludge also has a high COD concentration (2217 $\left.\mathrm{mg} \mathrm{O}_{2} \mathrm{~L}^{-1}\right)$. The direct discharge of such material into the environmental without any pre-treatment would represent a threat to the ecosystem of the receiving environment. The C: $\mathrm{N}$ or TOC: TKN ratio is equal to 11.6. This value is low and doesn't favor good anaerobic digestion, as it is reported in previous studies [28-29], during anaerobic digestion, microorganisms consume carbon 25-30 times faster than nitrogen. So therefore, for a good anaerobic digestion, it is recommended to keep the $\mathrm{C}: \mathrm{N}$ ratio between 20: 1 and 30: 1 . In this study, we didn't correct the $\mathrm{C}$ : $\mathrm{N}$ ratio because we want to avoid adding any other organic material to feces; but we added electron donors (micro iron powder $\mathrm{Fe})$ to catalyze the digestion as suggested by $[18 ; 20 ; 24-25]$ for sewage sludge.

Table 1. Physical and chemical parameters.

\begin{tabular}{llllllllll}
\hline Parameters & W & DM & pH & OM & COD & TA & TOC & TKN & TOC/TKN \\
Values & 82.5 & 17.5 & 7.6 & 94.7 & 2217 & 653.8 & 52.6 & 4.6 & 11.4 \\
\hline
\end{tabular}

Note: $\mathrm{W}, \mathrm{DM}, \mathrm{OM}, \mathrm{TOC}$ and TKN are in (\%), $\mathrm{COD}$ in $\left(\mathrm{mg} \mathrm{O}_{2} \mathrm{~kg}^{-1}\right)$ TA in $\mathrm{mg} \mathrm{CaCO}_{3} \mathrm{~kg}^{-1}$.

\subsection{Optimization of Fecal Sludge Digestion: Effect of Iron Powder}

\subsubsection{Biogas Production}

The evolution of biogas production, both daily and cumulative during anaerobic digestion is displayed in Figure $3 \mathrm{a}$ and $3 \mathrm{~b}$. 


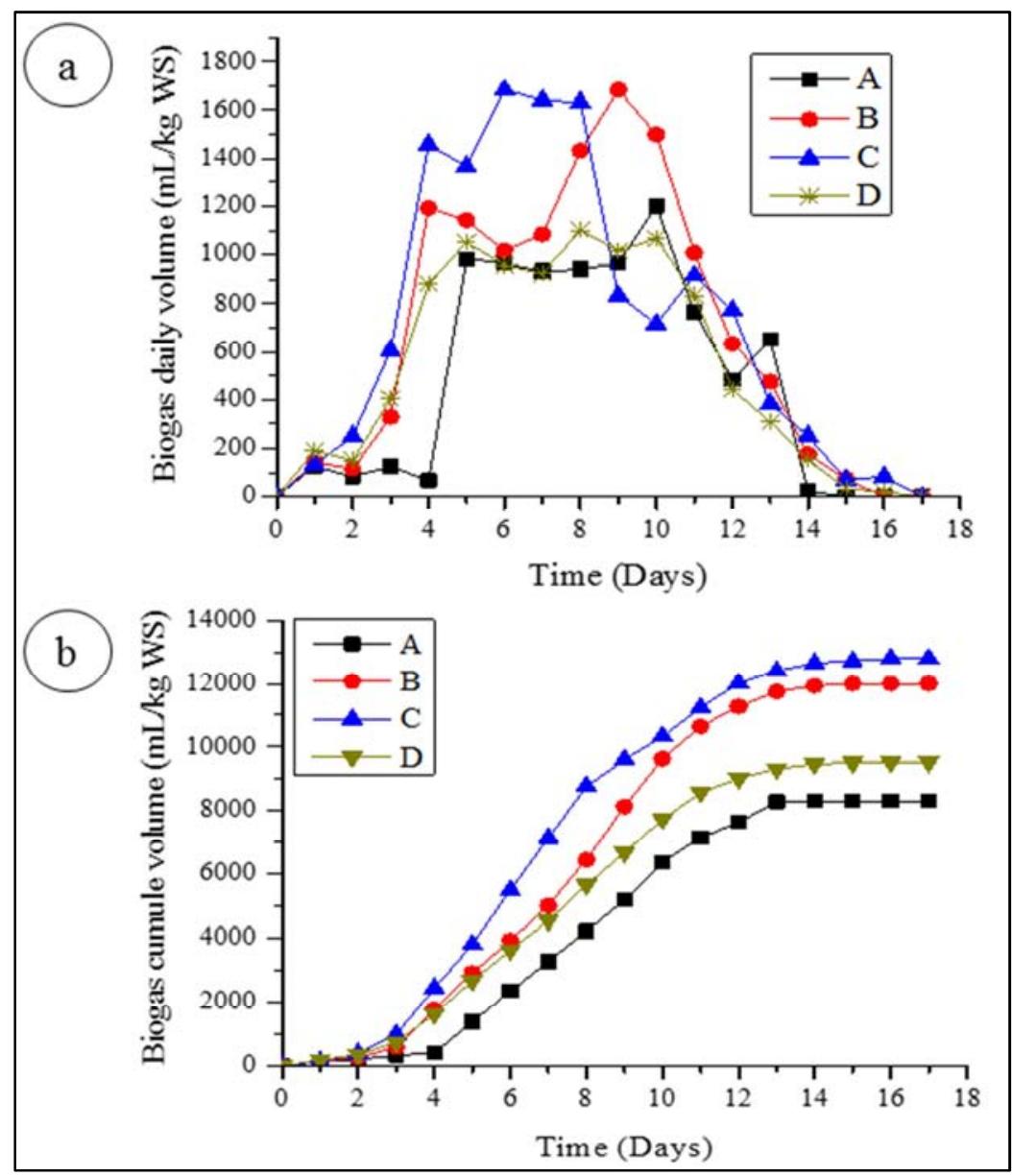

Figure 3. Biogas production in each digesters (a) daily volume and (b) cumulative volume.

Figure 3a shows the profile of the daily production of biogas in the different digesters. From the data, it can be observed low production of biogas as the consequence of low bacterial activity at the beginning of the experiment. In the digester A (control), it took 4 days for biogas to start being produced. In another word, it took 4 days for an intense activity of microorganisms to be noticed. This period of time is the acclimatization time during which microorganisms adapt to the material. After 4 days of acclimatization, a sudden increase in biogas production with a daily production up to $1000 \mathrm{~mL} \mathrm{~kg}^{-1}$ sludge on $5^{\text {th }}$ day of digestion can be noticed. Biogas production was kept around $1000 \mathrm{~mL} \mathrm{~kg}^{-1}$ till the $9^{\text {th }}$ day and then increased slightly to $1200 \mathrm{~mL} \mathrm{~kg}^{-1}$ sludge on the $10^{\text {th }}$ day. From the $10^{\text {th }}$ day biogas production dropped until the end of the process at the day 14. The sudden increase of the volume of biogas from the $4^{\text {th }}$ day reflects an intense bacterial activity. Indeed, during anaerobic digestion, microorganisms use organic carbon as energy source for the renewal of their cells. As a consequence organic matter are degraded and convert into biogas [24]. Biogas production decrease would explain the reduction in bacterial population due to the death of certain microorganisms during the degradation of organic matter. The deficit of "food" causes the death of microorganisms provoking the fall of biogas production. Unlikely to the control, the digesters B, C and D containing respectively $0.5 \mathrm{~g} ; 1 \mathrm{~g}$ and $3 \mathrm{~g}$ of iron powder have a relatively short acclimatization period ( 2 days) and intense bacteria activity was noticed earlier. A remarkable biogas production was noted from the second day until the $12^{\text {th }}$ day. As it can be seen, the duration of the anaerobic digestion was also shorten in those 3 digesters. The optimal biogas volumes obtained were respectively $1683 \mathrm{~mL} \mathrm{~kg}$ sludge, $1683 \mathrm{~mL} \mathrm{~kg}^{-1}$ sludge and $1100 \mathrm{~mL} \mathrm{~kg}^{-1}$ sludge respectively in the digesters $\mathrm{B}, \mathrm{C}$ and $\mathrm{D}$. Compared to the control (digester A), biogas production was remarkably improved in the digesters $\mathrm{B}$ and $\mathrm{C}$. A comparison of biogas production shows that digesters containing iron powder (B, $\mathrm{C}$, D) have a remarkable performance compared to the digester A. The total produced volume of biogas was estimated at $8315 \mathrm{~mL} \mathrm{~kg}^{-1}$ sludge, $12000 \mathrm{~mL} \mathrm{~kg}^{-1}$ sludge, $12800 \mathrm{~mL} \mathrm{~kg}^{-1}$ sludge and $9535 \mathrm{~mL} \mathrm{~kg}^{-1}$ sludge, respectively in the digesters A, B, C and D (Figure 3b). Results showed that the presence of iron powder in the digesters contributed to improve biogas production. Indeed, in a previous study on sewage sludge, it was proved that external supply of electron in an anaerobic digester enriched the environment and promoted better microorganisms' activity $[16 ; 18-19 ; 31]$. In this case with concentrations of 0.5 and $1 \mathrm{~g}$ of iron, the digestion of fecal sludge showed better performance. Otherwise, it is also found that in the digester D containing 3 $\mathrm{g}$ of iron powder biogas production considerably diminished compared to the digester $\mathrm{B}$ and $\mathrm{C}$ (Figure $3 \mathrm{~b}$ ). The same 
observation was noted by [30] then [24] in their study on the effect of zero valent iron nanoparticles $\left(\mathrm{Fe}^{0}\right)$ and magnetite $\left(\mathrm{Fe}_{3} \mathrm{O}_{4}\right)$ during anaerobic digestion of sewage sludge. It appeared that the concentration of iron powder which allows optimum biogas is comprised between $1.25 \mathrm{~g}$ and $2.5 \mathrm{~g}$ of $\mathrm{Fe}$ $\mathrm{kg}^{-1}$ fecal sludge. However, though $\mathrm{Fe}$ is not an environment metals of concern, in order to avoid iron overload in the digested sludge and environmental iron contamination, minimizing its amount in anaerobic digester would be interesting and promising. This emphasize the need of more investigation combining fecal sludge with others organic materials possessing high $\mathrm{C}: \mathrm{N}$ ratio.

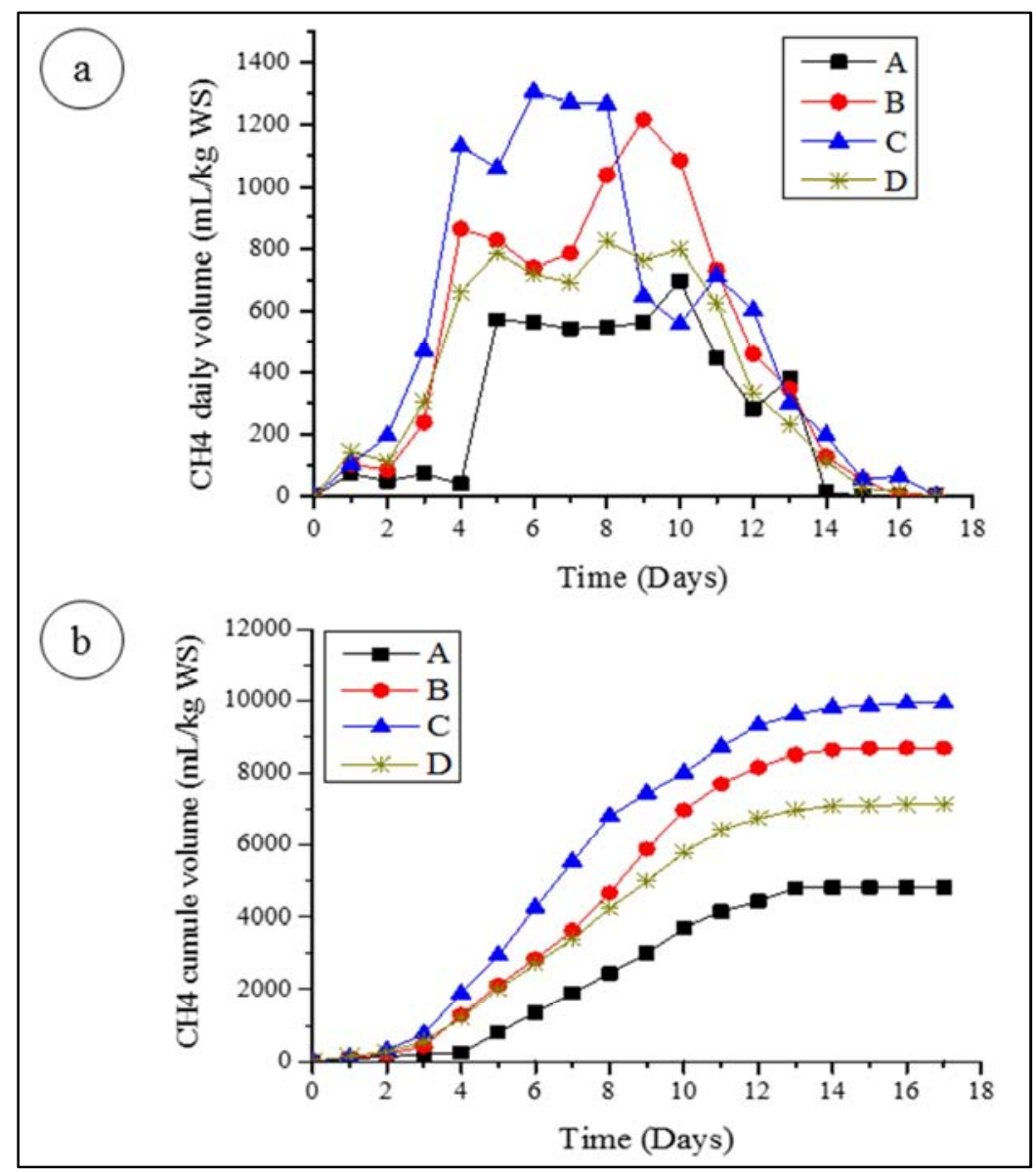

Figure 4. Methane production in each digesters (a) daily volume and (b) cumulative volume.

\subsubsection{Methane in the Biogas}

The second experimentation which consisted in adsorbing unwanted biogas such as $\mathrm{CO} 2$, in alkaline solution has permitted to directly measure the volume of methane gas. The result is shown in Figure 4a. One can clearly observe that methane production follows the same profile as that of biogas aforementioned. The effect of iron powder on methane production can quickly be noticed. Indeed, the presence of iron powder in the digesters B, C and D has significantly enhanced methane production compared to the digester A; which contained any trace of iron powder. The total volume of methane produced was: $4823 \mathrm{~mL} \mathrm{~kg}^{-1}$ sludge, $8688.5 \mathrm{~mL} \mathrm{~kg}^{-1}$ sludge, $9933 \mathrm{~mL} \mathrm{~kg}^{-1}$ sludge and $7132 \mathrm{~mL}$ $\mathrm{kg}^{-1}$ sludge, respectively in the digesters $\mathrm{A}, \mathrm{B}, \mathrm{C}$ and $\mathrm{D}$ (Figure $4 \mathrm{~b}$ ). It can thus be seen that compared to the control (digester A), the presence of iron powder has doubled the volume of methane in digesters $B$ and $C$. The best performance is obtained in the digester $\mathrm{C}$ containing $1 \mathrm{~g}$ of $\mathrm{Fe}$. This best performance of the anaerobic digestion and methane gas production in the presence of iron powder can be explained not only by the enrichment of bacterial activity in the environment due to the electron released in the biodigesters by the electron donors $\left(\mathrm{Fe} \rightarrow \mathrm{Fe}^{2+}+2 \mathrm{e}\right.$ or $\mathrm{Fe} \rightarrow$ $\left.\mathrm{Fe}^{3+}+3 \mathrm{e}\right)[16 ; 31]$; but also the imminent conversion of part of the $\mathrm{CO}_{2}$ produced to $\mathrm{CH}_{4}$ via the equation (2) $[15 ; 18]$. Consequently, the volume of produced methane increased while $\mathrm{CO} 2$ production considerably reduced. Furthermore, it has been also reported that part of produced $\mathrm{CO}_{2}$ could be converted into $\mathrm{CH}_{4}$ by fixing $\mathrm{H}_{2}$ (which could be produced during Fe corrosion) as showed in equation (3) [20]. The process of the reaction between $\mathrm{CO}_{2}$ and $\mathrm{H}_{2}$ could pass by an intermediary to methane, which will be further convert into methane (equation (4) and (5)) $[18 ; 25]$. Moreover, it has been given to us to notice that during the digestion, the unwanted odor caused by the formation of $\mathrm{H}_{2} \mathrm{~S}$ was greatly reduced as the sickening other decreased in the presence of iron powder. Indeed, $\mathrm{Fe}^{0}$ could remove toxic and biologically harmful compounds such as trace of $\mathrm{H}_{2} \mathrm{~S}$ by precipitating the produced $\mathrm{S}^{2-}$ via equation (6) and preventing the formation of 
$\mathrm{H}_{2} \mathrm{~S}$ responsible of the unwanted odor [15]. This would not only buffer the system and lead to more stable methane production but also better stabilized the sludge with less odor.

$$
\begin{gathered}
8 \mathrm{H}^{+}+4 \mathrm{Fe}^{0}+\mathrm{CO}_{2} \rightarrow \mathrm{CH}_{4}+4 \mathrm{Fe}^{2+}+2 \mathrm{H}_{2} \mathrm{O} \Delta \mathrm{G}^{0}=-150.5 \mathrm{~kJ} \mathrm{~mol}^{-1} \mathrm{CH}_{4} \\
4 \mathrm{H}_{2}+\mathrm{CO}_{2} \rightarrow \mathrm{CH}_{4}+2 \mathrm{H}_{2} \mathrm{O} ; \Delta \mathrm{G}^{0}=-131 \mathrm{~kJ} \mathrm{~mol}^{-1} \\
4 \mathrm{H}_{2}+2 \mathrm{CO}_{2} \rightarrow \mathrm{CH}_{3} \mathrm{COO}^{-}+\mathrm{H}^{+}+2 \mathrm{H}_{2} \mathrm{O} ; \Delta \mathrm{G}^{0}=-95 \mathrm{~kJ} \mathrm{~mol}^{-1} \\
\mathrm{CH}_{3} \mathrm{COO}^{-}+\mathrm{H}^{+} \rightarrow \mathrm{CH}_{4}+\mathrm{CO}_{2}, \Delta \mathrm{G}^{0}=-75.7 \mathrm{kJmol}^{-1} \\
\mathrm{Fe}+\mathrm{H}_{2} \mathrm{~S} \rightarrow \mathrm{FeS}+\mathrm{H}_{2}
\end{gathered}
$$

\subsubsection{Carbon Dioxide}

The effect of iron powder on methane production has been highlighted by evaluating the total volume of $\mathrm{CO}_{2}$ produced during the overall anaerobic digestion process in each digester (Figure 5). It can clearly be noted from the Figure that $\mathrm{CO}_{2}$ volume diminished with the concentration of iron powder. This would explained the increase of methane yield as aforementioned.

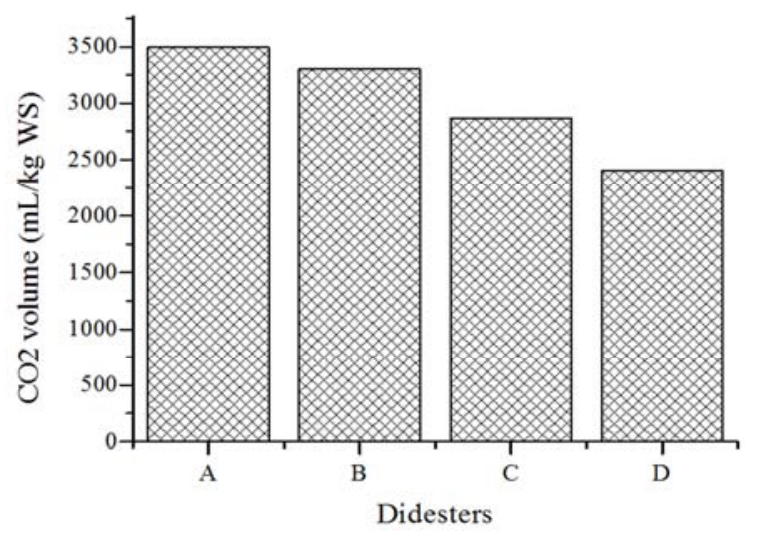

Figure 5. Produced carbon dioxide.

\subsubsection{Biogas Composition}

Based on the aforementioned results regarding biogas and methane production, and on the fact that biogas generally consists of methane and carbon dioxide [8-9], the composition of the produced biogas in each bio-digester was determined and results are shown in the Table 2. According the data, the presence of iron powder in the digesters enhanced methane concentration in biogas while decreased $\mathrm{CO}_{2}$ concentration. The highest percentage of methane achieved was $77.6 \%$ in the digester $\mathrm{C}$ containing $1 \mathrm{~g}$ Fe. To be noticed, although high concentration of $\mathrm{Fe}$ has a negative impact on the performance of microorganisms and biogas production in the digester $\mathrm{D}$, it did improve methane concentration.

Table 2. Composition of biogas in the digesters.

\begin{tabular}{lllll}
\hline Digesters & A & B & C & D \\
\hline$\%$ CH4 & 58.0 & 72.5 & 77.6 & 74.8 \\
$\% \mathrm{CO} 2$ & 42.0 & 27.5 & 22.4 & 25.2 \\
\hline
\end{tabular}

\section{3. $C O D$}

COD reduction is one of the main objectives to achieve during anaerobic digestion of organic wastes. Figure 6 displays the removal of COD during anaerobic digestion. The initial concentration of chemical oxygen demand in the fecal sludge was $2217 \mathrm{mg} \mathrm{O}_{2} \mathrm{~L}^{-1}$. In the current work, the presence of iron powder in the bioreactor significantly improved the COD abatement. Indeed, COD decreased from $2217 \mathrm{mg} \mathrm{L}^{-1}$ in the original fecal sludge to $1280.4 ; 885.4 ; 765.4$ and $1097 \mathrm{mg} \mathrm{L}^{-1}$, respectively in the digester $\mathrm{A}, \mathrm{B}, \mathrm{C}$ and $\mathrm{D}$, at the end of the digestion. Those values correspond respectively to a $42.2 \%$, $60.1 \%, 65.5 \%, 50.5 \%$ removal efficiency. The improvement of COD abatement in the presence of iron powder could be explained on one hand by the reduction power of $\mathrm{Fe}$ and by the anaerobic corrosion which undergoes Fe [32-33] on the other hand. According to the authors, during the anaerobic digestion, iron corrodes and an oxyhydroxide layer is forms on the surface of [32]. The oxyhydroxide layer formed provides sites for the adsorption of organic and inorganic pollutants [33]; which is reflected by the decrease of their concentration in the liquid phase of the digestate.

$$
\mathrm{Fe}^{0}+2 \mathrm{H}_{2} \mathrm{O} \rightarrow \mathrm{FeOOH}+1.5 \mathrm{H}_{2}
$$

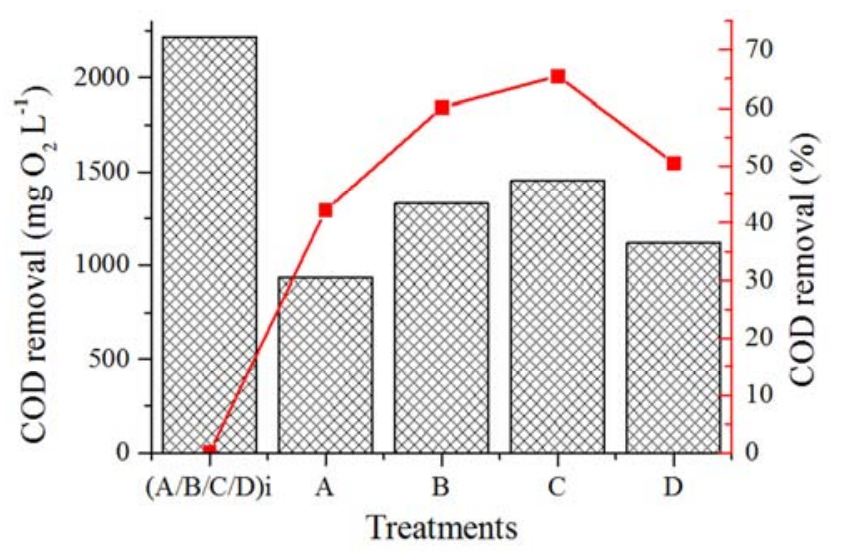

Figure 6. COD removal during sludge digestion $(i=$ initial $)$.

\section{Conclusion}

This study allowed us to appreciate the role of electron donors $(\mathrm{Fe})$ on fecal sludge valorization during anaerobic digestion process. It appeared from this study that the anaerobic digestion of fecal sludge alone does not yield good methane and digestate is not well stabilized with remarkable nauseating odor. But when adding iron powder is added in a reasonable amount (1.25 to $2.5 \mathrm{~g} \mathrm{~kg}^{-1}$ wet sludge), the process could be improved with a very good methane yield 
achievement. In addition, the abatement of COD was improved by $15 \%$ with the application of electron donor in anaerobic digester. Otherwise, the digested sludge was well stabilized with less odor, for further land application. Indeed, Fe could remove toxic and biologically harmful compounds such as trace of $\mathrm{H}_{2} \mathrm{~S}$ by precipitating the produced $\mathrm{S}^{2-}(\mathrm{Fe}+$ $\mathrm{H}_{2} \mathrm{~S} \rightarrow \mathrm{FeS}+\mathrm{H}_{2}$ ) and preventing the formation of $\mathrm{H}_{2} \mathrm{~S}$ responsible of the unwanted odor. However, though $\mathrm{Fe}$ is not an environmental metals of concern, in order to avoid environment iron contamination, reducing or minimizing its amount in anaerobic digester would be interesting and promising. Therefore, we are looking forward to investigating the co-digestion of fecal sludge and others organic materials with high $\mathrm{C}: \mathrm{N}$ ratio in the presence of iron powder.

\section{References}

[1] Panyadee S., Petiraksakul A., Phalakornkule C. (2013). Biogas production from co-digestion of Phyllanthus emblica residues and foodwaste. Energy Sustain Dev, 17 (5): 515-20.

[2] Owamah, H. I., Dahunsi, S. O., Oranusi, U. S., Alfa, M. I. (2014). Fertilizer and sanitary quality of digestate biofertilizer from the co-digestion of food waste and human excreta, Waste Management 34: 747-752.

[3] WHO-UNICEF. (2014). Progress on drinking water and sanitation 2014 update. Techn. Rep.; 2014 [http://www.who.int/water_sanitation_health/publications/201 4/jmp-report/en/ accessed May, 2015].

[4] Sridevi, V. D., Ramanujam, R. A. (2012). "Biogas Generation in a Vegetable Waste Anaerobic Digester: An Analytical Approach", Res. J. Recent Sci., 1: 41-47.

[5] Lee, I., Han, J-I. (2013). "The effects of waste-activated sludge pretreatment using hydrodynamic cavitation for methane production", Ultrason. Sonochem, 20: 1450-1455.

[6] BMGF (Bill and Melinda Gates Foundation). Water, sanitation \& hygiene. Strategy overview; 2011 [Seattle, USA. https://docs.gatesfoundation.org/Documents/wshstrategyoverview.pdf].

[7] Alburquerque, J. A., Fuente, C., Ferrer-Costa, A., Carrasco, L., Cegarra, J., Abad, M., Bernal, M. P. (2012). Assessment of the fertilizer potential of digestate from farm and agroindustrial residues. Biomass Bioenergy 40: 181-189.

[8] Lansing, S., Martin, J., Botero, R., Nogueira da Silva, T., Dias da Silva, E. (2010). Wastewater transformations and fertilizer value when codigesting differing ratios of swine manure and used cooking grease in low-cost digesters. Biomass Bioenergy 34: $1711-1720$.

[9] Goberna, M., Podmirseg, S. M., Waldhuber, S., Knapp, B. A., Garcia, C., Insam, H. (2011). Pathogenic bacteria and mineral $\mathrm{N}$ in soils following the land spreading of biogas digestates and fresh manure. Appl. Soil Ecology 49: 18-28.

[10] Snell J. (1943). Anaerobic digestion: III. Anaerobic digestion of undiluted human excreta. Sew Work J., 15 (4): 679-701.

[11] Colón J, Forbis-Strokes A, Ouksel L, Deshusses MA., (2013). Effective sewage sanitation with low $\mathrm{CO}_{2}$ footprint. 2nd
International Faecal Sludge Management Conference. Durban, South Africa; 2013. Canter LW, Knox RC. (1985). Septic tank system effects of ground water quality. Inc.: Lewis Publishers.

[12] Colón, J., Forbis-Stokes, A. A., Deshusses, A. M. (2015). Anaerobic digestion of undiluted simulant human excreta for sanitation and energy recovery in less-developed countries, Energy for Sustainable Development 29: 57-64.

[13] Luostarinen S, Sanders W, Kujawa-Roeleveld K, Zeeman G. (2007). Effect of temperature on anaerobic treatment of black water in UASB-septic tank systems. Bioresour. Technol. 98 (5): $980-986$.

[14] Li, X. Q., Brown, D. G., Zhang, W. X. (2007). Stabilization of biosolids with nanoscale zero-valent iron (nZVI), J Nanopart. Res. 9: 233-243.

[15] Liu, Y., Zhang, Y., Quan, X., Li, Y., Zhao, Z., Meng, X., Chen, S. (2012). "Optimization of anaerobic acidogenesis by adding $\mathrm{Fe}^{0}$ powder to enhance anaerobic wastewater treatment". Chem. Eng. J., 192: 179-185.

[16] Meng, X., Zhang, Y., Li, Q., Quan, X. (2013). Adding $\mathrm{Fe}^{0}$ powder to enhance the anaerobic conversion of propionate to acetate, Biochem. Eng. J., 73: 80-85.

[17] Feng, Y., Zhang, Y., Quan, X., Chen, S. (2014). Enhanced anaerobic digestion of waste activated sludge digestion by the addition of zero valent iron, Water Res. 52: 242-250.

[18] Zhang, Y., Feng, Y., Yu, Q., Xu, Z., Quan, X. (2014). Enhanced high-solids anaerobic digestion of waste activated sludge by the addition of scrap iron, Bioresour. Technol., 159: 297-304.

[19] Zhen, G., Lu, X., Li, Y-Y., Liu, Y., Zhao, Y. (2015). Influence of zero valent scrap iron (ZVSI) supply on methane production from waste activated sludge, Chem. Eng. J.. 263: 461-470.

[20] Su, L., Shi, X., Guo, G., Zhao, A., Zhao, Y. (2013). Stabilization of sewage sludge in the presence of nanoscale zero-valent iron (nZVI): abatement of odor and improvement of biogas production, J Mater Cycles Waste Manage. 15: 461468 .

[21] APHA. (2012). Standard methods for examination of water and waste-water, $22^{\text {nd }}$ ed. American Public Health Association, Washington DC.

[22] Igesias-Jimérnez, E., pérez-gracía, V. (1992). "Relationship between organic carbon and total organic carbon in municipal solid waste and city refuse composts", Bioressour. Technol., 41: 265-272.

[23] Suanon, F., Sun, Q., Mama, D., Li, J., Dimon, B., Yu, C-P. (2016). "Effect of nanoscale zero-valent iron and magnetite $\left(\mathrm{Fe}_{3} \mathrm{O}_{4}\right)$ on the fate of metals during anaerobic digestion of sludge", Water Res., 88: 897-903.

[24] Suanon, F., Sun, Q., Li, M., Cai, X., Zhang, Y., Yan, Y., Yu, CP. (2017). Application of nanoscale zero valent iron and iron powder during sludge anaerobic digestion: Impact on methane yield and pharmaceutical and personal care products degradation, J. Hazard. Mater. 321: 46-53.

[25] Ogejo, J. A., Wen, Z., Ignosh, J., Bendfeldt, E., Collins, E. R. (2009). Biomethane technology. Virginia Cooperative Extencion. Publication; 2009: 442-881. 
[26] Xie, S., Lawlor, P., Frost, J., Hu, Z., Zhan, X. (2011). "Effect of pig manure to grass silage ratio on methane production in batch anaerobic co-digestion of concentrated pig manure and grass silage”, Bioresour. Technol, 102: 5728-33.

[27] Tognetti, C., Mazzarino, M. J., Laos, F. (2007). "Improving the quality of municipal organic waste compost". Bioresour, Technol., 98: 1067-1076.

[28] Khalid, A., Arshad, M., Anjum, M., Mahmood, T., Dawson, L. (2011). "Review-the anaerobic digestion of solid organic waste". Waste Manage. 3; 11737-11744.

[29] Yang, Y., Guo, J., Hu, Z. (2013). "Impact of nano zero valent iron (NZVI) on methanogenic activity and population dynamics in anaerobic digestion", Water Res., 47: 6790-6800.
[30] Li, H., Chang, J., Liu, P., Fu, L., Ding, D., Lu, Y. (2015). "Direct interspecies electron transfer accelerates syntrophic oxidation of butyrate in paddy soil enrichments". Environ. Microbiol. 17: 1533-1547.

[31] Cornell, R. M., Schwartzman, U. (2003). "The Iron Oxides: Structure, Properties, Reactions, Occurrences and Uses, second ed". Weinheim Wiley-VCH., 2003.

[32] Esposito, G., Frunzo, L., Liotta, F., Panico, A., Pirozzi, F. (2012). "Bio-Methane Potential Tests To Measure The Biogas Production From The Digestion and Co-Digestion of Complex Organic Substrates", The Open Environ. Eng. J., 5: 1-8.

[33] Tang, N. S. C., and Lo, I. M. C. (2013). "Magnetic nanoparticles: Essential factors for sustainable environmental applications", Water Res., 47: 2613-2632. 